\title{
Does Financial Reporting Disclosures Enhance Firm Financial Performance in the Nigerian Manufacturing Companies?
}

\author{
Ojeka, Stephen Aanu (Corresponding Author)
}

Department of Accounting, College of Business Studies, Covenant University, Ota, Ogun State, Nigeria E-mail: Stephen.ojeka@covenantuniversity.edu.ng; stojeka@yahoo.com

Mukoro, Dick Oluku

Department of Accounting, College of Business Studies, Covenant University, Ota, Ogun State, Nigeria E-mail: Oluku.mukoro@covenantuniversity.edu.ng; dr.dickmukoro@yahoo.com

Kanu, Clementina

Department of Accountancy, Federal University, Ndufe Alike Ikwo, Ebonyi State, Nigeria

\section{Doi:10.5901/mjss.2015.v6n6p332}

\section{Abstract}

Financial reporting has always been an important factor for investment decision making of shareholders and other stakeholders of a firm in considering returns that have been made or expectation of what should be made. This study investigates empirically, the relationship between financial reporting disclosures in annual reports and the performance of listed manufacturing companies in Nigeria between 2005 and 2009. The disclosure variables include: Timeliness, Board size, type of Auditors Report and the percentage of value added retained for expansion were used as the measures of financial reporting disclosure while Return on Equity (ROE) was used as the measures of financial performance. Size and age were used as the control variables. The study used secondary data and Panel Least Square Regression for the data analysis. The results showed that there is a significant relationship between financial reporting disclosures and financial performance except in the case of percentage of value added retained for expansion size where there was no significant relationship found. It is, therefore, recommended that the Nigerian Federal Government, through her various regulatory agencies, ensure more disclosures is made in the financial report as this is an important means of addressing liquidity problem in the manufacturing sector for financial performance.

Keywords: Financial Reporting Disclosures, Financial performance, Manufacturing firms, Nigeria

\section{Introduction}

The extent of growth or performance of a firm is reported or communicated to the providers of capital and other stakeholders through the financial reports. Financial reporting plays an important role in decision making for a firm as it makes a framework for the analysis of the performance of the firm. Gray, Meeks and Roberts (1995) submitted that investors demand information in order to assess the timing and uncertainty of current and future cash flows so that they may evaluate firms and make other investment decisions such as choosing a portfolio of securities. It is a known fact that the extent to which business organizations report their activities especially as it has to do with finance, is one of the determining factors of the business performance and growth of the business organization (McMahon 1996).

When financial report is of high quality (especially as it has to do with disclosures), sourcing and attracting funds both locally and internationally become possible. Financial disclosures help users of financial report to know how exactly their resources are being utilized. It would also assist to predict the performance or otherwise of the business entity and most importantly, during the period of credit crunch that the Nigerian manufacturing companies is currently facing because the manufacturing sector remains a sensitive part of the Nigerian economy. It is the real sector that stimulates the gross domestic Product (GDP) of the country as a result of its various productive activities which involve, among many other contributions, the exportation of Nigerian made products to the rest of the world to boost foreign reserve and strengthen the Naira. The sector is also known for its job creation, especially for the young graduates, school levers and artisans. This sector is vital to the survival of the country and the actualization of the Millennium Development Goals 
(MDGs) development goals and, of course, the vision 20:2020.

Therefore, in the face of the dearth of investment in the manufacturing sector and, most especially, from the banking sector, there is need to focus strongly on how the manufacturing sector can begin to generate profit on its assets that will stimulate the growth of the sector. Therefore, one of the best ways to do this is to look critically at the reporting patterns of this sector especially the listed firms. This is to ensure that stakeholders (i.e. the providers of funds) have unlimited access to every detail in the financial report and able to understand all the facts behind the figures that have been produced. This is to encourage sourcing of funds at relatively low cost of capital which will ultimately lead to firm financial performance since the main focus of financial reporting is information about earnings and the components of earnings.

In order to achieve the above, the Securities and Exchange Commission codes 2011 (SEC Code, 2011) mandated listed firms to make certain information available for the users in form of disclosures in the financial report. The question, therefore, is, to what extent do the financial disclosures influence the financial performance of firms, especially in the manufacturing sector? Has the policy on financial disclosure made any significant contributions to the performance of firms and what has been the level of compliance thus far? Similar studies have been carried out in the contest of Nigeria (see Uwuigbe and Egbide, 2012; Mgbame, Otuya \& Ovie, 2013). These studies have focused on the extent of human resource accounting disclosures, environmental disclosures, and corporate social responsibility disclosure in the Nigerian firms. Thus the question still remains: what is the influence of financial disclosures on the firm financial performance in Nigeria? The objective of this study, therefore, is to find out the influence of financial disclosures on financial performance in the Nigerian manufacturing sector. The financial disclosure is decomposed into time lag, type of auditor's report, value added retained for expansion and board size while the financial performance is measured by Return on Equity (ROE).

The rest of the paper is structured into four parts. Part 2 discusses the literature and hypotheses development and part 3 the methodology, part 4 discusses the analysis and implication of findings while part 5 is the conclusion and recommendation.

To address the objectives already stated, the following hypothesis is proposed:

$\mathrm{H}_{0}$ : There is no significant relationship between Return on Equity (ROE) and Time Lag, external auditor's report, firm size, firm age, board size and value added retained for expansion of listed manufacturing companies in Nigeria.

\section{Literature Review}

\subsection{Financial Reporting Disclosures}

The financial reporting disclosures of companies are usually specified by the responsible regulatory agency. These disclosures are the basic tools used for communication between a company and its stakeholders. Dhaliwal, Khurana \& Pereira (2011) reasoned that disclosure is an important means through which the information of a firm is conveyed to the outside investors of the firm. The most important transactions of the company are usually represented in the financial statements as the mandatory disclosures while the voluntary disclosures are used to provide information that explain the mandatory disclosures better and satisfy the needs of the user. Hossain (2008) posited that the decision of management about whether to disclose information or not is based on weighing the expected costs and the benefits of making the information public.

The length of time taken by the auditors to perform their audit clearly has an effect on the timelines and the relevance of the financial reporting released to investors for investment decisions which means the more time passes between the year end and the disclosure date, the value of the information reduces and becomes less relevant (Wermert, Dodd, \& Doucet, 2000; Almosa \&Alabbas, 2008; Dumlu and Saltoglu (2011). Value added on the other hand is the worth of an investment in a company, which is a period that is equal to its sales less brought-in-goods and the statement of value added is more useful to the employees of a company than the income statement. It reports the calculation of value added and its application to the stakeholders of the company (Van Staden, 2000). Igben (2009) maintained that although there is no laid down format for the preparation of the value added statement in Nigeria, companies are required to include the statements in their annual reports.

In addition, in term of board size and composition, Yermack (1996), Sanda, Mikailu and Garba (2005) posited that small boards are more efficient in decision-making because there is less agency cost among the board members which is more associated positively with high firm performance. However, Kyereboah-Coleman (2007) differed and indicated that large boards enhanced shareholders' wealth more positively than smaller ones. But the issue here is that, does disclosing the board size in the financial report have any significant impact on the financial performance? Investors might be interested in the composition and the size to know the diversities and the calibre of the team they have entrusted their 
resources into. They might want to know the expertise of the board members to turnaround their interest and stake in the firm for maximum returns.

\section{Research Methods}

The focus of this study is on the manufacturing sector in Nigeria. According to the Nigerian Stock Exchange listings, the population of the manufacturing firms is 110. A sample size of 22 companies listed on the Nigerian Stock Exchange from 2005 to 2009 was selected using Yaro Yamani (1969) formula. This therefore resulted in 110 year observations for the study. In obtaining the sample of 22 , this study employed the judgmental non-probability sampling technique which was on the basis of availability and accessibility of the financial report of the chosen companies. The sectors include: Agriculture, Food and Beverage, Conglomerates, Health care, Building material, Industrial goods, Automobile, Breweries, Chemicals and paints. The firm performance was measured by Return on Equity (ROE) as the dependent variables while the independent variables were measured by namely: time lag, type of auditor's report, value added statement and board size.

Table 1: Summary of Variables Measurement/Description

\begin{tabular}{|l|l|l|}
\hline Name of variables & Acronym & Measurement \\
\hline Dependent Variable & & \\
\hline Return on Equity & ROE & PAT/Equity \\
\hline Independent Variables & & \\
\hline Time Lag in publication & TLIP & $\begin{array}{l}\text { It is calculated by the amount of days between the year or period end and the day } \\
\text { provided and signed by the independent auditors. }\end{array}$ \\
\hline Type of Auditors Report & TOAR & $\begin{array}{l}\text { The type of report which is prepared for the company in the financial statement by the } \\
\text { independent auditors whether qualified or unqualified report }\end{array}$ \\
\hline $\begin{array}{l}\text { Percentage of Value Added } \\
\text { Retained For Expansion }\end{array}$ & POVARE & $\begin{array}{l}\text { The disclosed percentage of the value added retained for expansion on the value added } \\
\text { statement }\end{array}$ \\
\hline Board Size & BSIZE & The number of people on the board as at the day of the year or period end. \\
\hline Size of the firm & FSIZE & This is sur This is the book value of the total asset of the firm at the end of financial year. \\
\hline Firm Age & FAGE & $\begin{array}{l}\text { This is measured as the number of years the company has been publicly traded or exists } \\
\text { since the first Annual General Meeting (AGM) }\end{array}$ \\
\hline
\end{tabular}

\subsection{Model Specification}

The mathematical description of the relationship existing between the variables (business performance and financial reporting disclosures) which will be analyzed with the use of the tools discussed above is represented below:

$Y=\beta_{0}+\beta X_{1}+\mu_{i t}$

Where, $Y$ is the dependent variable. $\beta 0$ is constant, $\beta$ is the coefficient of the independent variable (financial reporting disclosures), $\beta X 1$ is the independent variable and eit is the error term.

Representing equation (1) above in an econometric model, equation (2) below therefore becomes:

$R O E_{i t}=\beta_{0}+\beta_{1}$ TLIP $_{i t}+\beta_{2}$ TOAR $i t+\beta_{3}$ POVARE $E_{i t}+\beta_{4} B S I Z E_{i t}+\beta_{5} F S I Z E_{i t}+\beta_{6} A G E_{i t}+\mu_{i t . . . . .}$

\section{Analysis and Presentation of Results}

This section demonstrated and showcase different analyses of results and presentations on the data collected. The hypotheses were tested using the descriptive statistics, correlation coefficient and regression analysis. 


\subsection{Descriptive Statistics}

Table 2: Distribution of Sample

\begin{tabular}{|l|c|}
\hline SECTOR & Percentage (\%) \\
\hline FOOD AND BEVERAGE & 27 \\
\hline BUILDING MATERIALS & 17 \\
\hline AGRICULTURE & 9 \\
\hline BREWERIES & 9 \\
\hline CHEMICAL AND PAINTS & 5 \\
\hline HEALTHCARE & 14 \\
\hline INDUSTRIAL/DOMESTIC PRODUCTS & 5 \\
\hline CONGLOMERATES & 14 \\
\hline
\end{tabular}

Source: Authors' Survey (2015)

The table shows different sectors sampled and the companies represented in each sector. From the table, it was clear that Food and Beverage Sector contribute largely to the sample with $27 \%$ closely followed by building materials and then healthcare and conglomerates respectively. It also represents those firms that the financial statements were readily available for this study in term of data gathering.

Table 3: Univariate Analysis of the Sample

\begin{tabular}{|l|c|l|l|}
\hline Variables & Year Observations & Mean & Standard Deviation \\
\hline Return on Equity & 110 & 0.172546 & 0.5153167 \\
\hline Time Lag in publication & 110 & 108.6364 & 50.73003 \\
\hline Type of Auditor's Report & 110 & 3.954545 & 0.3143761 \\
\hline Board Size & 110 & 1.736364 & 0.9154863 \\
\hline Percentage of Value Added Retained for Expansion & 110 & 0.249545 & 167.5359 \\
\hline Size & 110 & 27000000 & 26700000 \\
\hline Age & 110 & 50.31818 & 12.69395 \\
\hline
\end{tabular}

Source: Authors' Survey (2015)

The table describes the means and standard deviation of both the dependent and explanatory variables across all the sectors sampled in this study. The average age of manufacturing firms listed in the Nigerian Stock Exchange stood at 50 years while it shows that, average percentage of value added retained for expansion, return on asset and return on equity are $24 \%, 10.9 \%$ and $17 \%$ respectively. This explains why the sector has not recorded significant improvements in Nigeria. This could be attributed to the high cost of production in term of electricity which has not been stable, cost of capital which is extremely high and of course the current devaluation of currency which has reduce the value of naira and increased cost of importation of raw material into Nigeria (Ojeka, Iyoha \& Obigbemi, 2014). In addition, the table explained the time lag which stood at average of 108 days. This means, the sector releases financial report early which makes it relevant for investors to make an informed investment decision. The table also shows the mean score of $17 \%$ for ROE. These low figure could be as a result of credit crunch that is permeating the system.

Table 4: Correlation Test of Multicollinearity of the Independent Variables

\begin{tabular}{|l|c|c|c|c|c|c|}
\hline Variable & TLIP & TOAR & BS & POVARFE & LOGSIZE & LOGAGE \\
\hline TLIP & 1.0000 & & & & & \\
\hline TOAR & -0.3859 & 1.0000 & & & & \\
\hline BS & 0.1052 & 0.0855 & 1.0000 & & & \\
\hline POVARFE & -0.0024 & 0.1103 & 0.0348 & 1.0000 & & \\
\hline LOGSIZE & -0.2620 & 0.0662 & -0.4010 & 0.2045 & 1.0000 & \\
\hline LOGAGE & -0.1297 & 0.0100 & 0.0228 & 0.0111 & 0.2690 & 1.0000 \\
\hline
\end{tabular}

Source: Authors' Survey (2015) 
The report in table 4 indicates that, there is no presence of multicollinearity among the explanatory variables as none of the coefficients is greater than 0.7. As postulated by Tabachnik and Fidell (1996) that, the maximum correlation coefficient is 0.7 and any coefficient above this, the researcher can consider omitting one of the variables or forming a composite variable from the scores of the two highly correlated variables. This therefore shows that the issue of spurious results from the regression analysis would not occur.

\subsection{Multiple Linear Regression Analysis}

Table 5: Regression Results: Whole Sample

\begin{tabular}{|c|c|c|}
\hline \multirow{5}{*}{ Independent Variables (Financial reporting disclosures) } & & Dependent Variables \\
\hline & \multirow{4}{*}{ Predicted Sign } & ROE \\
\hline & & Coefficient \\
\hline & & (t-statistics) \\
\hline & & P-value \\
\hline TLIP & + & $\begin{array}{c}-0.0028^{\star \star \star} \\
(-3.05) \\
0.003\end{array}$ \\
\hline TOAR & + & $\begin{array}{c}0.4125^{\star \star \star} \\
(2.82) \\
0.006\end{array}$ \\
\hline BSIZE & ? & $\begin{array}{l}0.1370 \\
(2.68) \\
0.009^{*}\end{array}$ \\
\hline POVARFE & + & $\begin{array}{c}-0.0002 \\
(-0.99) \\
0.324\end{array}$ \\
\hline FSIZE & + & $\begin{array}{c}0.1129^{\star \star \star} \\
(3.22) \\
0.002\end{array}$ \\
\hline AGE & + & $\begin{array}{c}-0.1326 \\
(-0.73) \\
0.468\end{array}$ \\
\hline Constant & & $\begin{array}{c}-2.722^{* *} \\
(-2.62) \\
0 . .010\end{array}$ \\
\hline $\begin{array}{l}\text { P-value } \\
\text { F-test } \\
R^{2} \\
R^{2} \text { Adjusted } \\
\text { No of Obs. }\end{array}$ & & $\begin{array}{c}0.000 \\
8.23 \\
0.324 \\
0.2289 \\
110\end{array}$ \\
\hline \multicolumn{3}{|c|}{$\begin{array}{l}\text { Note: ROE in this table represents Return on Equity, and it represents one of the business performance variables for this } \\
\text { study. Also, three indicators representing financial reporting disclosures in this study are: TLIP represents Time Lag in } \\
\text { publication, TOAR represents Type Of Auditors Report, BS represents Board Size, POVARE represents Percentage Of } \\
\text { Value Added Retained For Expansion, LOGSIZE represents log of the size of the company, LOGAGE represents log of the } \\
\text { age of the company. }{ }^{* *}=\text { significant at } 1 \% \text {; }{ }^{*}=\text { significant at } 5 \% ;{ }^{*}=\text { significant at } 10 \%\end{array}$} \\
\hline
\end{tabular}

From the results in Table 4.1, the time lag in publication (TLIP) has negative coefficients with return on equity (ROE) and was significant at $1 \%, 5 \%$ and $10 \%$ level but percentage of value added retained for expansion (POVARFE) though with negative coefficient was not significant. However, age of the firm (FMAGE) had a negative coefficient but was insignificant at all levels. Also, type of auditor's report, board size and firm size (FMSIZE) all had positive coefficients and were significant against ROE at $1 \%, 5 \%$ and $10 \%$ level.

The implication of these findings is that, the disclosures of some of the variables considered in this study as specified by various regulatory authorities in term of: type of auditor's report, board size and size of the company influenced the perception of the stakeholders about the firm. Stakeholders in Nigeria are drawn to firms whose auditor's report are not qualified and do away with firm in which the financial report does not pass the test of the external auditors. 
This is one of the cardinal disclosures mandated by Security and Exchange Commission in Nigeria. A vivid example is the Cadbury saga and the recent illiquidity problem in the Nigerian banking sector. In addition, the size of the board is also very important in term of experience and quality decision making. This help in measuring the qualitative factors that drive the firm. Prior studied have looked at the significance of board size on financial performance (see KyereboahColeman, 2007, Ojeka, Iyoha and Obigbemi, 2014, Ojeka, Iyoha and Asaolu, 2015) Also, the disclosure of the firm is equally very important. Potential investor(s) for example want to consider the financial position of the firm. Firms in Nigeria have used this means to mislead some gullible investors into believing that the firm is doing well only to discover otherwise. Some firms adjust the size of the firm to what the public want to see thereby making the financial report unreliable for decision making.

Surprisingly, time lag in publication (TLIP), percentage of value added retained for expansion (POVARFE) and firm age (FMAGA) all showed negative coefficients against return on equity (ROE). This means these variables do not really weigh on the decision of the investors. For example, in Nigeria, some new generation banks are doing quite well and some new account holders prefer new generation banks in term of innovativeness, adaptation to new information technologies and speed in the processing of transaction compare to old generation banks. This analogy also applied to some firms in the manufacturing sector in Nigeria. The result in term of time lag is however in contrast to findings in Ojeka, Iyoha and Asaolu (2015) where they found positive relationship between time lag and audit committee financial expertise. Though, the study did not consider if the finding influences investors investment decisions as contained in this study.

\section{Conclusion and Recommendation}

This study investigated the relationship between financial reporting disclosures and firm financial performance in the manufacturing sector in Nigeria. The results showed that financial reporting disclosures especially the explanatory variables considered in this study have a significant positive impact in driving the financial performance of firms in the manufacturing firms in Nigeria. It also point out to say that shareholders and investors are motivated to surrender funds for equity finance when certain disclosures are made in the financial report. Hence this study submitted that, the new International Financial Reporting Standards (IFRS) which is hoped to encourage more disclosures would further help to strengthen the financial performance of the firms.

Therefore, the federal government through the various regulatory agencies should ensure more disclosures are made, which will guide investors in their decisions whether to invest or not to. This paper further recommend that, apart from the statutorily disclosures, any firm(s) willing to experience sustainable financial performance and expansion, especially during the liquidity problem currently experiencing in the economy, should strive to ensure that all that the investors need to know are disclosed in the financial report, in order to sustain the loyalty and commitment of the shareholders in term of equity. For example, banks which are the major source of finance to the real sector currently were hit the more as the tapering effect combined with the continued monetary policy tightening by the Central Bank of Nigeria caused investors to dump the stocks. Cash Reserve Requirement on public sector deposits which is likely to be raised to 100 per cent with that of private sector deposits also set to be increased to 15. Consequently, if this happens, the banks will still thrive to grow earnings via a better cost management, increasing focus on non-interest income, and growth in loan books, especially to real sector. As a result, the uncertainties in the global economy, monetary policy tightening and political tensions and the recent depression in the market which has also been linked to the suspension of the Central Bank Governor may further worsen the already deteriorating situation making it impossible for the real sector to access funds or at a very high cost of capital.

This study like other previous studies does have its limitation and therefore, the conclusions drawn should be interpreted with caution which would invariably serve as opportunities for further investigation in future research in this area this is because the study captured the listed manufacturing sector in Nigeria. Therefore, companies which operate in the financial sector are excluded since they have special practices and operations. This could be looked at in future research work.

\section{References}

Almosa, S. A. \& Alabbas, M. (2008). Audit Delay: Evidence from listed joint stock companies in Saudi Arabia. Working paper, King Khalid University.

Dhaliwal, D. S., \& Khurana, I. K., \& Pereira, R. Firm (2011) Disclosure policy and the choice between private and public debt. Contemporary Accounting Research, 28(1), 293-330. 
Dumlu, T. \& Saltoglu, M. (2011). the timeliness of annual reports in Turkey: An Empirical Study. Modav, 1, 1-22

Igben, R. O. (2009). Financial Accounting Made Simple Volume 2 ( $3^{\text {rd }}$ ed.). Isolo, Lagos State, Nigeria: ROI Publishers.

Hossain, M. (2008). the extent of disclosure in annual reports of Banking companies: The case of India. European Journal of Scientific Research, 23(4), 660-681.

Kyereboah-Coleman, A. (2007). Corporate Governance and Firm Performance in Africa: A Dynamic Panel Data Analysis. Being a paper prepared for the International Conference on Corporate Governance in Emerging Markets. Retrieved February 04, 2012 from

McMahon, R.G.(1996) Business growth and performance and the financial reporitng practices of Australian manufacturing SMEs. School of Commerce, Research Paper Series: 98-7, ISSN 1441-3906

Meek, G., Roberts, C., Gray, S. (1995). Factors influencing voluntarily annual report disclosure by U.S., U.K., and continental European multinational corporations. Journal of International Business Studies, 26, 555-572.

Ojeka S.A, Iyoha F.O. and Obigbemi I.F (2014), Effectiveness of Audit Committee and Firm Financial Performance in Nigeria: An Empirical Analysis", Journal of Accounting and Auditing: Research \& Practice, Vol. 2014 (2014)

Ojeka, S.A., Iyoha, F.O., and Asaolu, T. (2015). Audit committee financial expertise: Antidote for financial reporting quality? Mediterranean Journal of Social Sciences. (Scopus)Italy

Van Staden, C. J., (2000). Revisiting the value added statement: to publish or not to publish. In Proceedings of the $12^{\text {th }}$ Asian Pacific Conference on International Accounting Issues, 21-42, pp.20-23.

Wermert, J. G., Dodd, J.L. \& Doucet, T.A. (2000). an empirical examination of audit report lag using client and audit firm cycles times. Working Paper, Drake University

Yermack, D. (1996). Higher market valuation of companies a small board of directors. Journal of Financial Economics, 40, 185-202. 